\title{
ENVIRONMENTAL EFFECT OF CO-FIRING AND MAGNETIC FIELD ON WOOD PELLETS COMBUSTION
}

\author{
Vera Suzdalenko, Martins Gedrovics \\ Institute of Energy System and Environment, Riga Technical University, Riga, Latvia \\ Submitted 21 May 2013; accepted 03 Oct. 2013
}

\begin{abstract}
The aim of the recent research is to provide stable, controllable and effective wood pellets combustion with minimum emissions. Two possibilities were chosen, investigated and analysed: wood pellets co-firing with propanebutane mixture and the use of a permanent magnet. The special pilot device was constructed in the laboratory of Heat and Mass Transfer in Institute of Physics. Two types of experiments were conducted: combustion with propane-butane supply ( $0.9 \mathrm{~kW}$ up to $1.27 \mathrm{~kW}$ ) of wood pellets with different moisture content (W = 8\%, 15\%, 20\% and 25\%); combustion of wood pellets with applied magnetic field by using the permanent magnet, an propane-butane supply also was used. The main conclusion of the research is that co-firing and magnetic field can be used as an instrument to provide more effective burnout of volatiles and cleaner heat production.
\end{abstract}

Keywords: air pollution, wood pellets, propane-butane mixture, co-firing, magnetic field, clean and effective heat energy production.

Reference to this paper should be made as follows: Suzdalenko, V.; Gedrovics, M. 2014. Environmental effect of cofiring and magnetic field on wood pellets combustion, Journal of Environmental Engineering and Landscape Management 22(02): 115-124. http://dx.doi.org/10.3846/16486897.2013.852559

\section{Introduction}

Biomass is renewable energy resource that is used for environmentally friendly energy production due to carbon dioxide $\left(\mathrm{CO}_{2}\right)$ neutrality and relatively low nitrogen oxide $\left(\mathrm{NO}_{\mathrm{x}}\right.$ ) emissions (Balat 2008). The biomass combustion involves a number of complicated physical and chemical processes:

- biomass drying: $\mathrm{T}>373 \mathrm{~K}$;

- pyrolysis and gasification: $\mathrm{T}=500-1373 \mathrm{~K}$;

- oxidation: $\mathrm{T}>1373 \mathrm{~K}, \alpha>1$ (Shen et al. 2009; Balat 2009; Nussbaumer 2003; Obernberger, Thek 2004; Van Loo, Koppejan 2008).

The use of wood fuel (firewood, wood chips, pellets, briquettes and wastes) is gradually increasing in the Baltic States (Table 1). The biggest part of wood fuel is used in households; at the same time the use of wood fuel in transformation sector (heat and electricity production) is not high. There are many reasons for that: wood fuel has different moisture content and heating value, combustion efficiency is not as high if comparing with natural gas (Arena et al. 2010; Demirbas 2004; Vassilev et al. 2010).
Table 1. The use of wood fuel (PJ) in the Baltic States

\begin{tabular}{lcccc}
\hline Country & Year & $\begin{array}{c}\text { Gross } \\
\text { consump- } \\
\text { tion }\end{array}$ & $\begin{array}{c}\text { Consump- } \\
\text { tion in } \\
\text { energy } \\
\text { sector }\end{array}$ & $\begin{array}{c}\text { Final con- } \\
\text { sumption } \\
\text { in house- } \\
\text { holds }\end{array}$ \\
\hline $\begin{array}{l}\text { Latvia }(1)^{*} \\
\text { Lithuania }\end{array}$ & & 39.7 & 5.1 & 28.2 \\
$(2)^{*}$ & 2000 & 23.7 & 0.0 & 19.3 \\
$\begin{array}{l}\text { Estonia } \\
(3)^{*}\end{array}$ & & 20.7 & 6.9 & 13.9 \\
\hline Latvia & & 49.4 & 7.1 & 32.1 \\
Lithuania & 2005 & 30.5 & 0.0 & 20.4 \\
Estonia & & 22.9 & 9.9 & 12.3 \\
\hline Latvia & & 46.9 & 6.9 & 26.1 \\
Lithuania & 2011 & 33.3 & 0.0 & 20.5 \\
Estonia & & 51.5 & 32.9 & 18.1 \\
\hline Baltic & 2000 & 84.1 & 12.0 & 61.4 \\
States & 2005 & 102.8 & 17.0 & 64.8 \\
\hline$*(1)$ Source: & 2011 & 131.7 & 39.8 & 64.7 \\
\hline
\end{tabular}

* (1) Source: Statistical database of the Republic of Latvia;

* (2) Source: Statistics of Lithuania;

* (3) Source: Statistics of Estonia.

Corresponding author: Vera Suzdalenko

E-mail: vera.suzdalenko@rtu.lv 
The aim of recent research is to study wood pellets combustion improvement possibilities by using different regulation possibilities:

- wood pellets co-firing with gaseous fossil fuel;

- applying of magnetic field during wood pellets combustion and co-firing.

Co-firing is a combustion process when two or more fuel types are combusted in the same furnace. There is a growing interest in biomass and fossil fuel co-firing (Van Loo, Koppejan 2008; Williams et al. 2012). By replacing fossil fuel with renewable resource (RES) it is possible to reach the main goal of the European Union climate and energy package: to reduce greenhouse gas emissions, to increase RES share in energy balance (European Commission ...). There are over 150 installations worldwide in which are co-fired different types of fuel (Al-Mansour, $\mathrm{Zu}$ wala 2010). Prevalent coal is co-fired with different types of biomass thus reducing $\mathrm{CO}_{2}, \mathrm{SO}_{2}$ and $\mathrm{NO}_{\mathrm{x}}$ emissions. The biomass share in this co-firing process ranges from $1 \%$ to $20 \%$ depending on combustion applications.

Natural gas is the friendliest fossil fuel (no $\mathrm{SO}_{2}$ emissions, PM), however there are not many examples of natural gas substituting with biomass. There is CHP plant in Denmark, where wood chips are co-fired with natural gas. The moisture content of wood chips is varied from $20 \%$ to $60 \%$ (max) (DongEnergy ...). From previous researches (Barmina et al. 2009; Zake et al. 2009) it was concluded that gas and wood fuel co-firing promotes the enhanced wood fuel gasification at the primary stage of the swirling flame formation, while the additional heat injection into

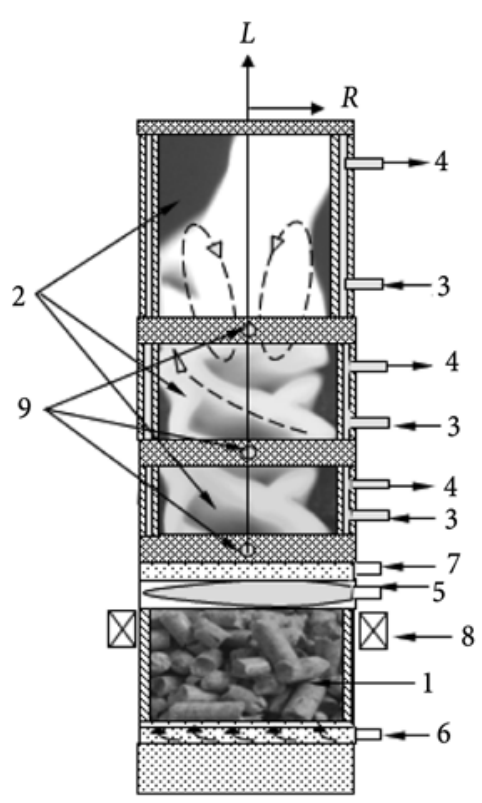

Fig. 1. Pilot scale-up: 1 - wood fuel gasifier; 2 - water-cooled combustor; 3 - inlets of cooling water flow; 4 - outlets of cooling water flow; 5 - gas burner; 6 - nozzle of primary air supply; 7 - nozzle of secondary air flow; 8 - permanent magnets; 9 - diagnostic sections the flame reaction zone results with an enhanced burnout of the volatiles.

Another possibility for more effective volatiles combustion and heat production is to apply a magnetic field. The magnetic field gradient influences the flame behaviour (shapes, sizes), rate of heat production and combustion efficiency (Nagaraju 2005; Swaminathan 2005). It is explained that magnetic field provides the field-induced mass transfer of paramagnetic flame components $\left(\mathrm{O}_{2}\right.$ and $\mathrm{NO}_{\mathrm{x}}$ ) in the field direction but diamagnetic flame species $\left(\mathrm{CO}, \mathrm{H}_{2}, \mathrm{CO}_{2}\right.$, etc.) indicates a weak repulsion by the magnetic field with direct impact on combustion conditions (Arima et al. 1999; Gilard et al. 2008). This behaviour of flame species that depends on the volume of magnetic susceptibility of paramagnetic and diamagnetic flame species $\left(\chi_{v}\right)$, magnetic induction (B) and magnetic gradient $(\mathrm{dB} /$ dL) can be used as a tool to control combustion.

\section{Experimental set-up}

The experimental research was carried out by using a batch size pilot device with a maximum capacity of $2 \mathrm{~kW}$ that was specially constructed in the laboratory of Heat and Mass Transfer Institute of Physics (University of Latvia).

The pilot device is composed of wood fuel gasifier (1), sections of water-cooled combustor (2), inlets (3) and outlets (4) of cooling water flow, gas burner (5), and swirling air nozzles with tangential inlets of primary (6) and secondary (7) air supply and diagnostic sections (9). The total length of the pilot device was $700 \mathrm{~mm}$, the diameter $-60 \mathrm{~mm}$.

The air in the pilot device was supplied in two places: primary air was supplied below wood fuel layer initiating wood fuel gasification; the secondary air was supplied above the gas burner and it provided the gradual mixing of the swirling air flow of volatiles and gradual burnout of volatiles.

- The complex measurements for providing the investigation of co-firing and magnetic field influence on wood pellets combustion were done by using diagnostic sections. The following measurements were provided;

- The measurements of the flame temperature by using Pt/Pt-Rh thermocouples;

- The measurements of the axial and tangential velocity of the flame compounds by using the Pitot's tube;

- The measurements of the flame compositions $\left(\mathrm{O}_{2}\right.$, $\mathrm{CO}, \mathrm{CO}_{2}, \mathrm{NO}_{\mathrm{x}}$ ) and combustion efficiency were performed by using the gas analyzer TESTO $350 \mathrm{XL}$.

In order to obtain a valid data about the processes that take place on the combustion chamber, the measurement instruments were inserted at different height values depending on the series of experiment. 
Table 2. The placement of the measurement instruments above the propane-butane burner

\begin{tabular}{lcc}
\hline & Co-firing & Magnetic field \\
\hline First thermocouple & 157 & 55 \\
Second thermocouple & 187 & 380 \\
Gas analyser, Pitot's tube & 380 & 145 \\
\hline
\end{tabular}

Thermocouples were placed in the centre of the channel $(R=0)$, while the gas analyser probe and Pitot's tube were placed according to the aim of the experiment either in the centre of the channel $(\mathrm{R}=0)$ in case of making kinetic measurements of the flame composition, or were moved radially in the channel when making measurements of the flame composition and radial distribution of velocity in the steady combustion process. Measurements of the flame composition and radial distribution of velocity were made moving the probes with an interval of 30 second in the direction from the centre of the flame to the channel wall and backwards. The data registration was carried out with time interval of 1 second.

As it was mentioned before, two possibilities to provide clean and effective heat energy production were investigated. The characteristics of used fuel and combustion conditions are described below.

\section{The co-firing of wood pellets and propane-butane mixture}

Wood pellets with different moisture content ( $W=8 \%$, $15 \%, 20 \%$ and $25 \%$ ) was co-fired with propane-butane mixture. The heat combustion of wood pellets was varied from $14.11 \mathrm{MJ} / \mathrm{kg}$ for wood with moisture content $25 \%$ up to $17.32 \mathrm{MJ} / \mathrm{kg}$ for wood with moisture content $8 \%$. The discrete doses $(500 \mathrm{~g})$ of wood pellets were combusted during all experiments.

Self-sustaining wood pellets combustion was compared with co-firing process. Non-stationary combustion process was provided during experimental research. Propane-butane supply was varied from $0.9 \mathrm{~kW}$ up to $1.27 \mathrm{~kW}$. It was used to initiate gasification of wood pellets and complete the burnout of volatiles.

The primary air was supplied with rate $47 \mathrm{l} / \mathrm{min}$; the secondary air-supplying rate was $69 \mathrm{l} / \mathrm{min}$. The average amount of air that was supplied in the pilot device was $5.4 \mathrm{~nm}^{3}$. The air excess ( $\alpha$ ) was varied from 2.5 up to 3.07 depending on moisture content of wood pellets.

\section{The applying of magnetic field}

The permanent magnet (8) with 4 pairs of poles, which height is $50 \mathrm{~mm}$, was attached below the secondary air supply and gas burner in order to produce axial and tangential transfer of paramagnetic oxygen molecules to the pellet layer surface, thus providing more complete mixing of volatiles and air at the primary stage of combustion process.

Magnetic induction (B) above the magnet poles reached its maximal value of $120 \mathrm{mT}$ at the outer wall of the channel. Axial gradient of the magnetic field gradient $(\mathrm{dB} / \mathrm{dL})$ at the wall of the channel, which caused oxygen transfer towards the pellet surface was equal to $1.56 \mathrm{~T} / \mathrm{m}$, but it was not higher than $0.8 \mathrm{~T} / \mathrm{m}$ in the central part of the flame.

Wood pellets were combusted with or without propane-butane supply during the investigation of magnetic field influence. The moisture content of wood pellets was $8 \%$. Discrete doses ( $320 \mathrm{~g}$ ) of wood pellets were combusted during the experiments. The propane-butane supply was varied from $1.27 \mathrm{~kW}$ up to $1.55 \mathrm{~kW}$. The primary air was supplied with the rate of $47 \mathrm{l} / \mathrm{min}$, but secondary air was supplied with the rate of $71 \mathrm{l} / \mathrm{min}$.

\section{Results and discussion}

\subsection{The effect of wood pellets co-firing with gaseous fossil fuel}

The process of wood pellets combustion starts with wood pellets endothermic heating, drying and thermal decomposition processes. The thermal decomposition of wood is related to formation of volatiles $\left(\mathrm{CO}, \mathrm{H}_{2}, \mathrm{C}_{\mathrm{x}} \mathrm{H}_{\mathrm{y}}\right)$ and its exothermal ignition and combustion that promotes rapid increase of temperature till it reaches maximum value. The effect of moisture content in wood pellets and propanebutane supply on ignition of fuel is shown in Table 3 .

Table 3. The influence of moisture content in wood pellets and propane-butane supply on fuel ignition

\begin{tabular}{lcccc}
\hline $\begin{array}{l}\text { Moisture content of } \\
\text { wood pellets, \% }\end{array}$ & 8 & 8 & 25 & 25 \\
\hline $\begin{array}{l}\text { Propane-butane } \\
\text { supply, kW }\end{array}$ & 0 & 1,27 & 0 & 1,27 \\
$\begin{array}{l}\text { Maximum } \\
\text { temperature, K }\end{array}$ & 1821 & 1984 & 1699 & 1923 \\
Time* $^{\star}$ s & 445 & 175 & 875 & 479 \\
\hline
\end{tabular}

* when maximum temperature was reached.

Investigations with wood pellets of different moisture and different supply of propane-butane in the device (Fig. 2) confirm that in the term of the beginning of thermal decomposition stage essentially depends on content of moisture and supply of propane-butane to wood pellets. While combustion of wood pellets with $8 \%$ moisture content with propane-butane supply and without propane/butane supply to wood pellets, inflammation of volatile compounds has been noticed, comparing wood pellets combustion with $25 \%$ moist, faster reaching maximal temperature of combustion zone (Table 3). While increasing 

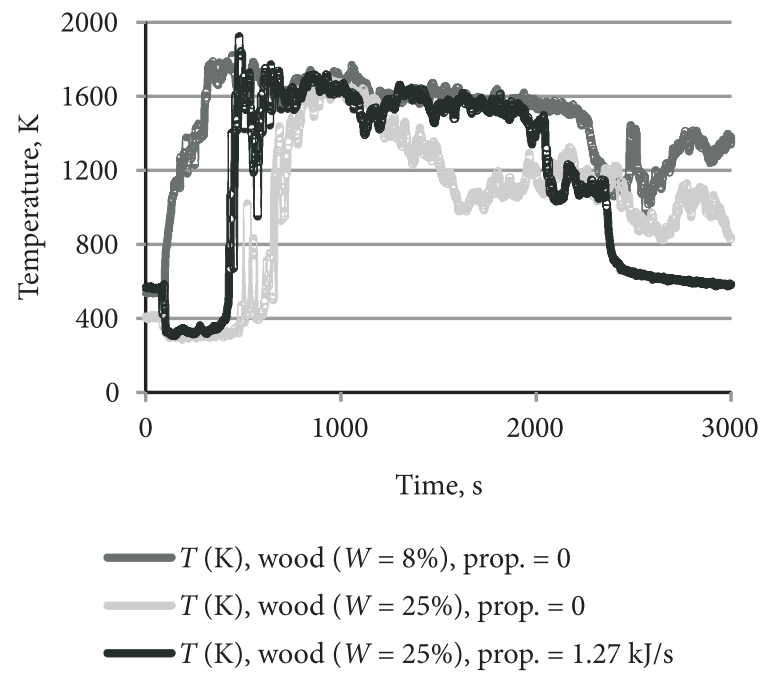

Fig. 2. Temperature changes (K) for wood pellets of different moisture content combustion with and without propanebutane supply
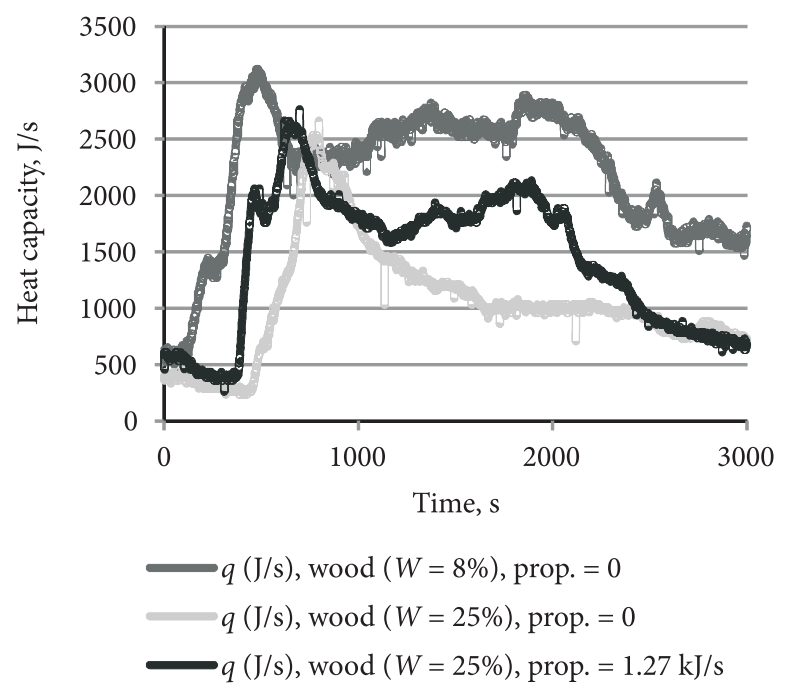

Fig. 3. The effect of wood pellets moisture content and propane-butane supply on heat production rate

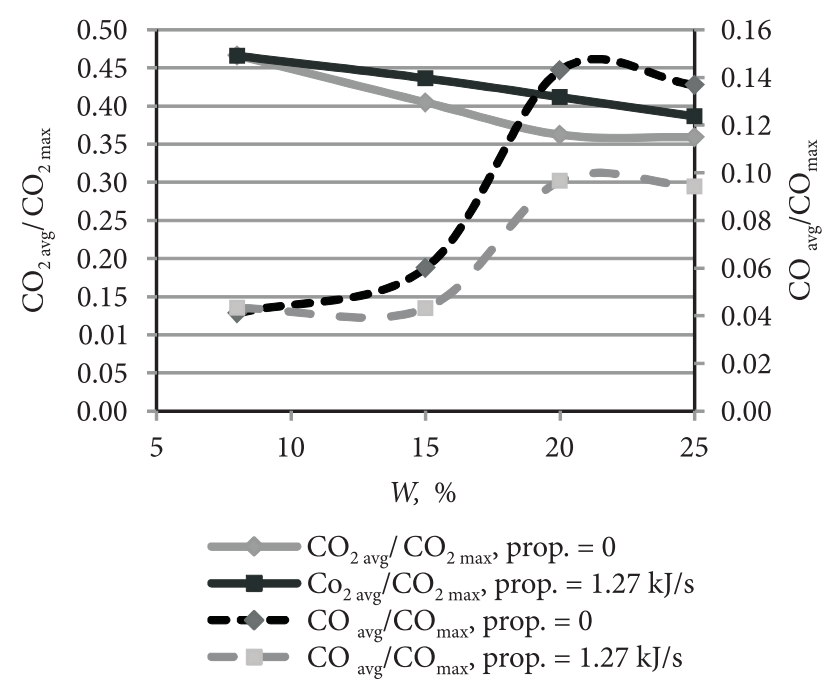

Fig. 4. $\mathrm{CO}_{2 \text { avg }} / \mathrm{CO}_{2 \max }$ and $\mathrm{CO}_{\text {avg }} / \mathrm{CO}_{\max }$ dependence on moisture content in wood pellets for different combustion condition moisture content in wood pellets, temperature in the beginning of thermal decomposition process decreases (after $100^{\text {th }}$ second), because endometrial processes of wood heating and drying dominate, thus limiting development of volatile compounds and inflammation.

After evaluating results of experimental measuring of the influence of wood pellets moisture content and propane-butane supply on average temperature of combustion zone, the following empirical equation has been obtained:

$$
T=1715.23-27.15 W+117.83 q,
$$

where: $W$ - moisture content in wood pellets (\%); $q$ - supply of propane-butane $(\mathrm{kW})$.

Using regressions analysis derives this equation and all equations below.

As a result of experimental investigations it is stated that supply of propane-butane to wood pellets layer provides not only higher temperatures, but also increases heat production rate $(Q)$, which can be seen on Figure 3 .

Greater heat production rate was observed when combustion of wood pellets with lower moisture content ( $W=8 \%$ ) took place and vice versa - the lowest values of heat production rate were notified when were used wood pellets with the highest moisture content ( $W=25 \%)$ (Fig. 3). Similarly to temperature changes (Fig. 2), heat production rate is depended on moisture content in wood pellets and propane-butane supply at the beginning.

The evaluation of produced heat $(Q)$ in the device depending on moisture content of wood pellets and supply of propane-butane to the device revealed mutual interconnectedness of the parameters in the empiric equation:

$$
Q=2.42-0.08 W+0.35 q \text {, }
$$

where: $W$ - moisture content in wood pellets (\%); $q$ - supply of propane-butane $(\mathrm{kW})$.

The influence of propane-butane and moisture content of wood pellets on $\mathrm{CO}_{2}$ and $\mathrm{CO}$ emissions has been evaluated during the experiment by attributing average $\mathrm{CO}_{2}$ and $\mathrm{CO}$ emisions to the maximal value. In case of $\mathrm{CO}$ it was maximal value, which was reached during the experiment, but maximal quantity of $\mathrm{CO}_{2}$ was calculated depending on supply of propane-butane $(\mathrm{kW})$.

Wood pellets moisture content influences development of $\mathrm{CO}_{2}$ emission during combustion, as well as its concentration in products. If the wood pellets moisture content is increased, $\mathrm{CO}_{2}$ emissions decrease, but quantity of CO emissions increases. Supply of propane-butane to combustion camera intensifies wood pellets combustion process, increasing $\mathrm{CO}_{2}$ concentration, but decreasing $\mathrm{CO}$ concentration in products (Fig. 4).

The effect of moisture content on $\mathrm{CO}$ emissions is described in Bignal K. L. research (Bignal et al. 2008). There was found that moisture content in wood biomass and boiler operation conditions affect concentration of 
pollutant. The increasing of moisture content in biomass fuel affects the increase of $\mathrm{CO}$ emissions. It was found the relationship of $\mathrm{CO}$ and $\mathrm{PAH}$ emissions: high $\mathrm{CO}$ concentrations correlated with an increase of PAH.

The results of experimental investigations confirm that current correlations can be described with empirical equations:

$$
\begin{gathered}
\frac{\mathrm{CO}_{2 a v g}}{\mathrm{CO}_{2 \max }}=0.49-0.01 W+0.03 q ; \\
\frac{\mathrm{CO}_{\text {avg }}}{\mathrm{CO}_{\text {max }}}=-0.001-0.006 \mathrm{~W}-0.0391 q,
\end{gathered}
$$

where: $W$ - moisture content in wood pellets (\%); $q$ - supply of propane-butane $(\mathrm{kW})$.

For total combustion of wood pellets and gas mixture, sufficient air supply should be provided $(\alpha \geq 1)$. With wood pellet moisture content increase, theoretically sufficient air volume for fuel combustion decreases, whereas during the experiments the same air volume has been supplied not depending on the wood pellets moisture content. Due to that reason coefficient of air excess increases from 2.5 to 3.07 with wood pellets moisture content increase from $8 \%$ to $25 \%$ and the process of wood pellets combustion develops at expressed odd air supply in the device.

When the moisture content in wood pellets increases, $\mathrm{O}_{\text {2avg. }} / \mathrm{O}_{2 \max }\left(\mathrm{O}_{2 \max }=21 \%\right)$ increases and average $\mathrm{O}_{2}$ concentration in products increases, which confirms that in case of moisture increase in pellets, less air should be supplied for total burn-off of the fuel. At the same time combusting wood pellets with supply of propane-butane to the device, increase of relative $\mathrm{O}_{2 \text { avg. }} / \mathrm{O}_{2 \max }$ volume concentration in products is slightly lower, because supply of propane-butane increases average temperature of combustion zone (Fig. 2), providing complete combustion of volatile compounds (Fig. 4).

Analysis of experimental results confirms that influence of wood pellets moisture content and supply of propane-butane on changes in relative $\mathrm{O}_{2 \text { avg. }} / \mathrm{O}_{2 \max }$ volume concentration can be approximately characterized using empirical equation:

$$
\frac{\mathrm{O}_{2 a v g}}{\mathrm{O}_{2 \max }}=0.52+0.01 \mathrm{~W}-0.06 q,
$$

where: $W$ - moisture content in wood pellets (\%); $q$ - supply of propane-butane $(\mathrm{kW})$.

$\mathrm{NO}_{\mathrm{x}}$ emission during combustion process is essentially influenced by the temperature at combustion zone, air supply in the device, as well as nitrogen content in the biomass (Stubenberger et al. 2008; Williams et al. 2012). The experimental results (Fig. 2) and regression Equation (1) confirmed that average temperature decreased by increasing moisture content in wood pellets, but increased if propane-butane was supplied. At the same time the

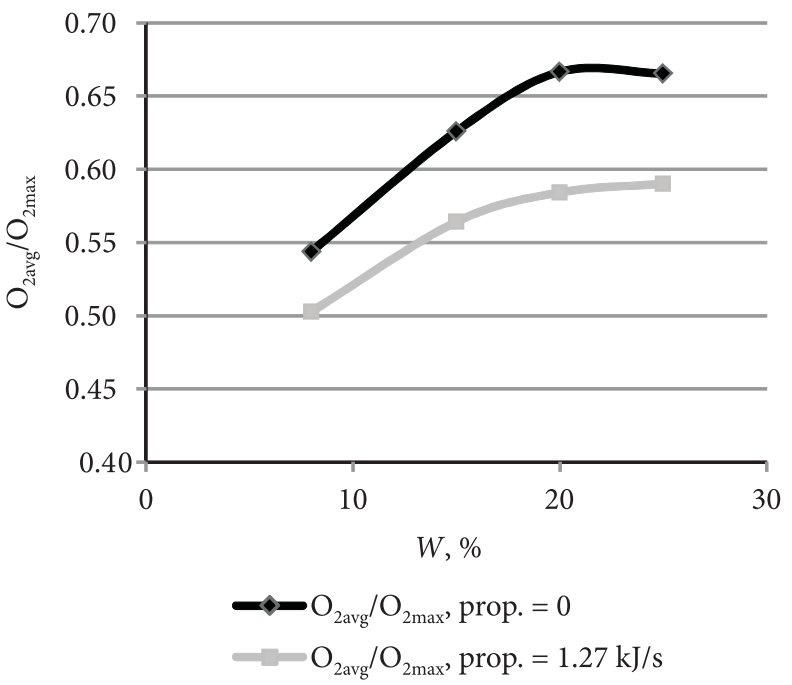

Fig. 5. The $\mathrm{O}_{\text {2avg. }} / \mathrm{O}_{2 \max }$ changes in products depending on moisture content in wood pellets and supply of propane-butane in combustion zone

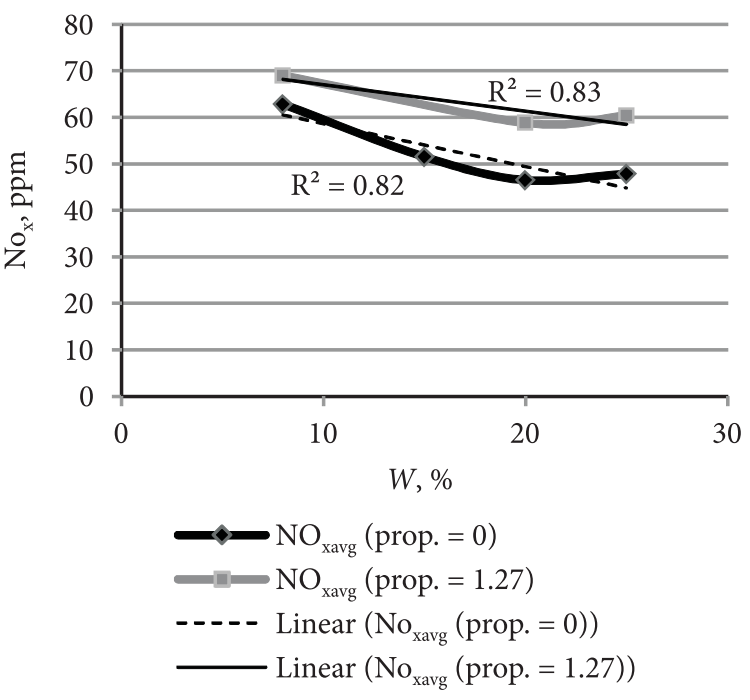

Fig. 6. The $\mathrm{NO}_{\text {xavg. }} / \mathrm{NO}_{\text {xmax }}$ changes in products depending on moisture content in wood pellets and supply of propane-butane in combustion zone

average concentration of oxygen increased by increasing moisture content in wood pellets (Fig. 5). It should be noticed that increasing moisture content also changes elementary composition of wood pellets. All these factors impact the formation of $\mathrm{NO}_{\mathrm{x}}$ emissions in combustion zone. The impact of moisture content in wood fuel and propane-butane supply on $\mathrm{NO}_{\mathrm{x}}$ formation is illustrated in Figure 6.

The amount of $\mathrm{NO}_{\mathrm{x}}$ emissions decreased for self-sustaining wood fuel combustion and for combustion with propane-butane supply by increasing moisture content in wood fuel (Fig. 6). The same results was founded in (Bhattacharya et al. 2002) during wood fuel combustion.

Results of the experimental measuring show that influence of wood pellets moisture content and supply of propane-butane on relative changes of $\mathrm{NO}_{\text {xavg. }} / \mathrm{NO}_{\text {xmax }}$ can 
be described using Equation (6). $\mathrm{NO}_{\text {xavg. }}$ is an average value during the experiment, but $\mathrm{NO}_{x \max }$ - maximal value during the experiment.

$$
\frac{N O_{x a v g}}{N O_{x \max }}=0.65-0.01 \mathrm{~W}+0.12 q,
$$

where: $W$ - moisture content in wood pellets (\%); $q-$ supply of propane-butane $(\mathrm{kW})$.

While combusting the biomass it is important to arrange combustion process not only with limited exhaust of hazardous emission into atmosphere, but also higher heat production and efficiency of combustion process should be provided. While proceeding experimental data on efficiency of combustion, it is stated that supply of propane-butane and changes in wood pellets moisture content influence efficiency of the combustion process $(\eta)$, which increases with higher supply of propane-butane to the combustion zone and decreases with higher moisture content in wood pellets (Fig. 7).

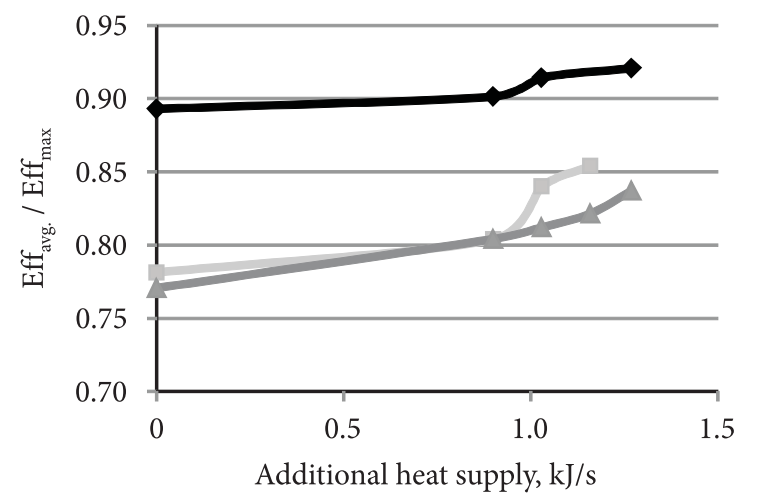

$$
\begin{aligned}
& \longrightarrow \eta \operatorname{avg} / \eta \max (W=8 \%)-\eta_{\operatorname{avg} / \eta \max }(W=15 \%) \\
& \sim \eta_{\operatorname{avg} / \eta \max }(W=20 \%)
\end{aligned}
$$

Fig. 7. $\eta_{\text {avg }} / \eta_{\max }$ at different velocity of propane-butane supply and at different moisture content in wood pellets

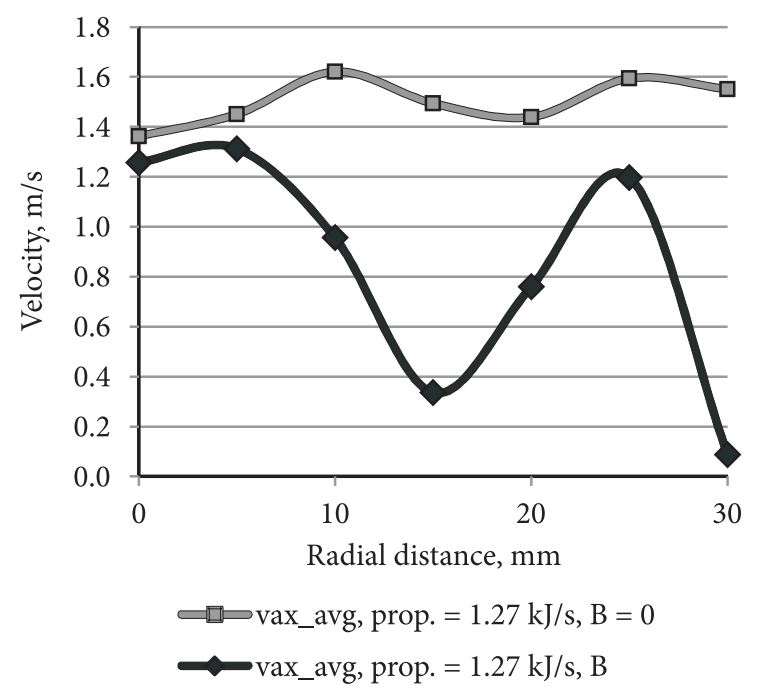

Fig. 8. Effect of magnetic field on formation of flame axial (a) and tangential (b) velocity distribution in the process of cofiring
The influence of moisture content in wood pellets and propane-butane supply on efficiency can be described with equation:

$$
\frac{\eta_{\text {avg }}}{\eta_{\max }}=0.93-0.008 W+0.04 q,
$$

where: $W$ - moisture content in wood pellets (\%); $q$ - supply of propane-butane $(\mathrm{kW})$.

The effect of moisture content on efficiency was investigated by Bhattacharya S. C. (Bhattacharya et al. 2002). There was concluded that the efficiency decreased with increase of moisture content in biomass fuel. At the same time it was concluded (Yuntenwi et al. 2008) that extremely dry biomass fuel inhibited combustion efficiency.

\subsection{The influence of magnetic field on wood pellets combustion and co-firing with propane-butane}

The results of previous investigations (Zake et al. 2010; Suzdalenko et al. 2011) confirm that effects of interaction between flame and inhomogeneous magnetic field can be used in order to achieve additional impact on the combustion process. The effect is based on transfer of paramagnetic oxygen towards the gradient caused by the magnetic field gradient. It provides fluctuations of local oxygen concentrations in the air and in volatile mixtures with the following changes in combustion of volatiles.

Influence of the magnetic field gradient $(\mathrm{dB} / \mathrm{dL})$ on the flow dynamics is mainly defined by the magnetic force $\left(\mathrm{F}_{\mathrm{mag}}\right)$, which depends on the magnetic susceptibility of the oxygen $\left(\chi_{v}\right)$ and magnetic permeability $\left(\mu_{0}\right)$. Force generated by the magnetic field gradient defines fluctuations of the swirling flow dynamics, followed by fluctuations in volatile matter combustion process.

As the result of the interaction of the magnetic field gradient generated force and the flame fluctuations of swirling flow dynamics are observed with an evident reduction of axial and tangential velocity of the flame (Fig. 8). Considering this a forecast can be made that in the process of magnetic field and flame interaction length of volatile matter containment in the combustion zone will increase, providing more complete combustion of volatile matters.

Supply of propane-butane in the combustion zone and impact of the magnetic field on formation of flame axial and tangential velocity distribution are related to the fluctuations of the swirling flow number (S), which defines the formation of recirculation zone and intensity of swirling flow (Fig. 9). The results of the experimental measurements prove that increase of propane-butane supply to the combustion chamber gradually reduces the swirling flow of the flame. Accordingly, axial increase of velocity caused by the supply of propane-butane limits formation of the recirculation flow. 
Influence of the magnetic field on combustion process emissions, temperature, and produced heat energy was investigated and evaluated also in the process of wood pellet combustion with supply of propane-butane at the bottom of the combustion zone, while changing supply of propane-butane from $1.27 \mathrm{~kW}$ till $1.55 \mathrm{~kW}$. These experimental data were compared with the process of wood pellet and gaseous mixture co-firing process, where magnetic field was not applied $(B=0)$. Average parameter values were calculated for the data analysis. These average values obtained from the experiments with magnetic field $(B)$ were divided by the average values obtained from the experiments without magnetic field $(B=0)$ (in the Figures it is marked as $B /(B=0))$.

Figure 10 shows how $\mathrm{O}_{2}(B) / \mathrm{O}_{2}(B=0)$ ratio depends on supply of propane-butane during the experiments.

When wood pellets are combusted without supply of propane-butane (prop.-but. $=0 \mathrm{~kW}$ ) in the bottom of the combustion zone, $\mathrm{O}_{2}(B) / \mathrm{O}_{2}(B=0)$ ratio is greater than 1 . It means that average amount of oxygen at the bottom of the combustion zone increases if paramagnetic oxygen transfer is intensified along the magnetic field. At the same time if wood pellets are combusted with supply of propane-butane in the bottom of the combustion zone, $\mathrm{O}_{2}(B) / \mathrm{O}_{2}(B=$ $0)$ ratio reduces, which indicates reduction of the average amount of oxygen. Basically this can be explained with the fact that in case if wood pellets are combusted with supply of propane-butane additional heating of paramagnetic oxygen is provided, ensuring transfer of hotter heat flow to the pellet surface. This improves gasification of the wood pellets and provides more intensive formation of volatiles.

In contrast to the changes of oxygen concentration, a higher $\mathrm{CO}_{2}(B) / \mathrm{CO}_{2}(B=0)$ ratio for wood pellet combustion process is observed when supply of propane-butane to the bottom of the combustion zone is increased (Fig. 11). More complete volatile combustion can be achieved by combining supply of propane-butane at the bottom of combustion zone with magnetic force produced paramagnetic oxygen transfer.

The effect of propane-butane supply on $\mathrm{CO}_{2}(B) /$ $\mathrm{CO}_{2}(B=0)$ ratio can be described with linear equation:

$$
\frac{\mathrm{CO}_{2}(B)}{\mathrm{CO}_{2}(B=0)}=0.25 q+0.77,
$$

where: $q$ - supply of propane-butane $(\mathrm{kW})$.

After influence of magnetic field and supply of propane-butane on concentration of CO emissions is stated that supply of propane-butane ensures reduction of $\mathrm{CO}(B) /$ $\mathrm{CO}(B=0)$ ratio (Fig. 11). The highest $\mathrm{CO}(B) / \mathrm{CO}(B=0)$ ratio is observed if wood pellets are combusted without supply of propane-butane at the bottom of combustion zone, when paramagnetic oxygen transfer stimulates formation of air excess and temperature reduction. When supply of propane-butane is provided, this ratio decreases

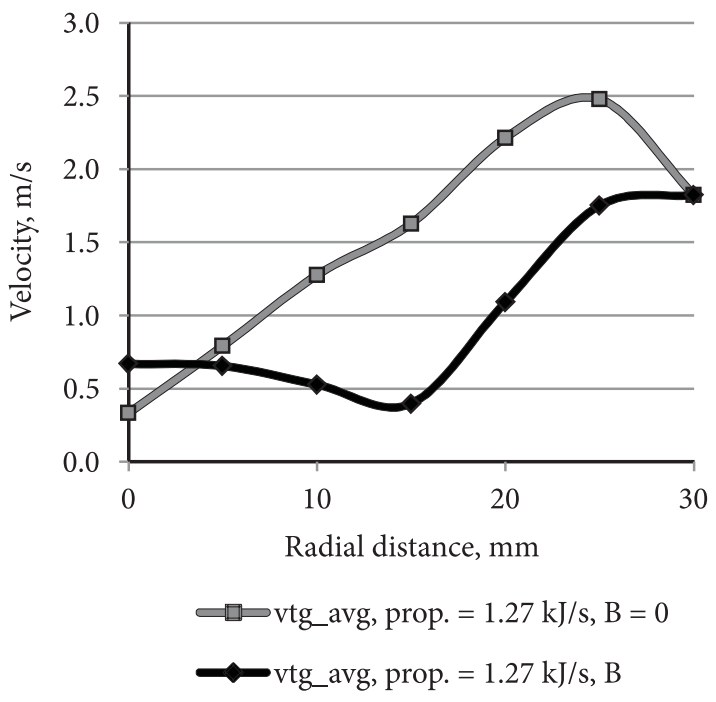

Fig. 9. Influence of propane-butane supply and magnetic field on swirling flow number

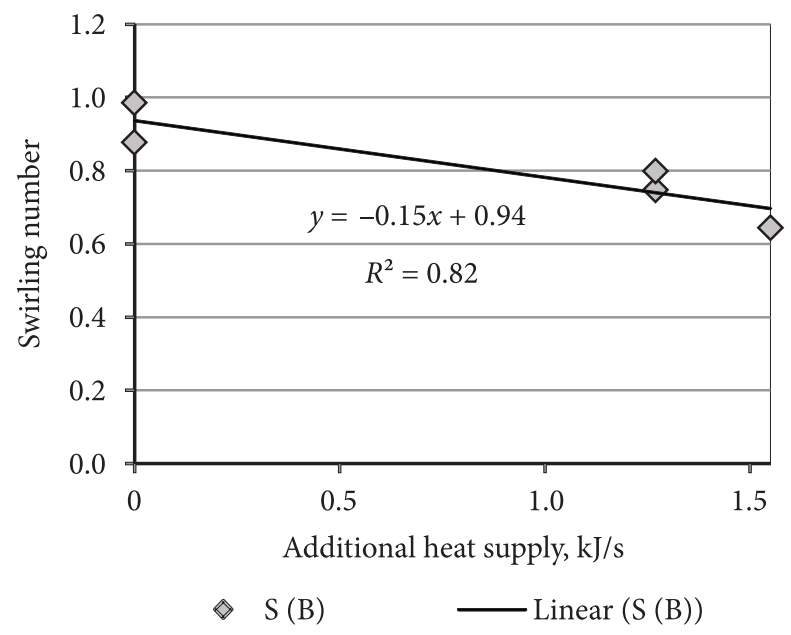

Fig. 10. Influence of propane-butane supply on $\mathrm{O}_{2}(\mathrm{~B}) / \mathrm{O}_{2}(\mathrm{~B}=$ 0) ratio

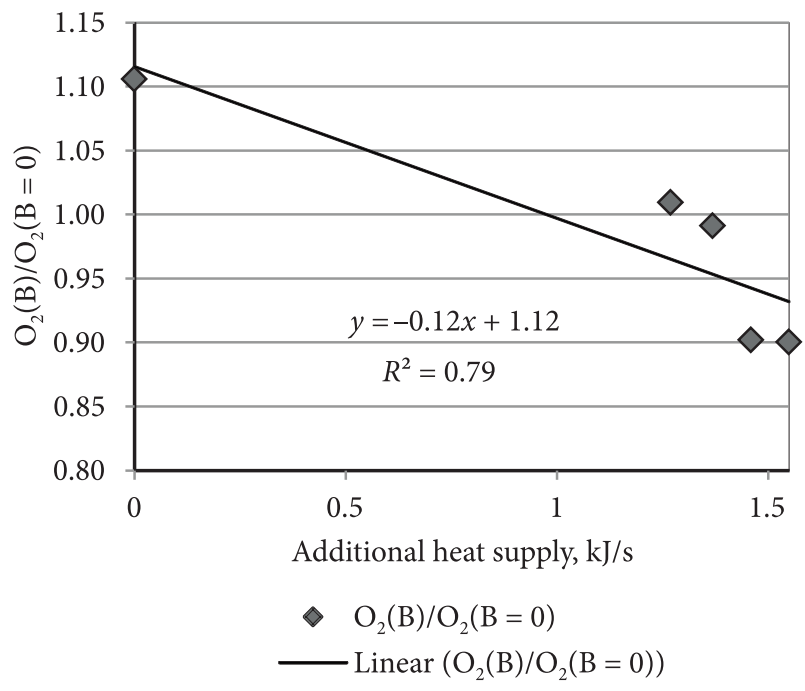

Fig. 11. Influence of propane-butane supply on $\mathrm{CO}_{2}(\mathrm{~B}) /$ $\mathrm{CO}_{2}(\mathrm{~B}=0)$ and $\mathrm{CO}(\mathrm{B}) / \mathrm{CO}(\mathrm{B}=0)$ ratio 
and provides more complete combustion process as well as decreases release of harmful CO emissions into the environment. Influence of propane-butane supply on $\mathrm{CO}(B)$ / $\mathrm{CO}(B=0)$ is described with the following linear equation:

$$
\frac{\mathrm{CO}(B)}{\mathrm{CO}(B=0)}=-0.28 q+1.28,
$$

where: $q$ - supply of propane-butane $(\mathrm{kW})$.

Paramagnetic oxygen transfer caused by the magnetic field and supply of propane-butane at the bottom of combustion zone influence also formation of $\mathrm{NO}_{\mathrm{x}}$. The results of the experimental research on influence of this factor on fluctuation of $\mathrm{NO}_{\mathrm{x}}(B) / \mathrm{NO}_{\mathrm{x}}(B=0)$ are summarized in Figure 12.

As it is seen from Figure 12 in the process of wood pellet combustion $\mathrm{NO}_{\mathrm{x}}(B) / \mathrm{NO}_{\mathrm{x}}(B=0)$ ratio increases,

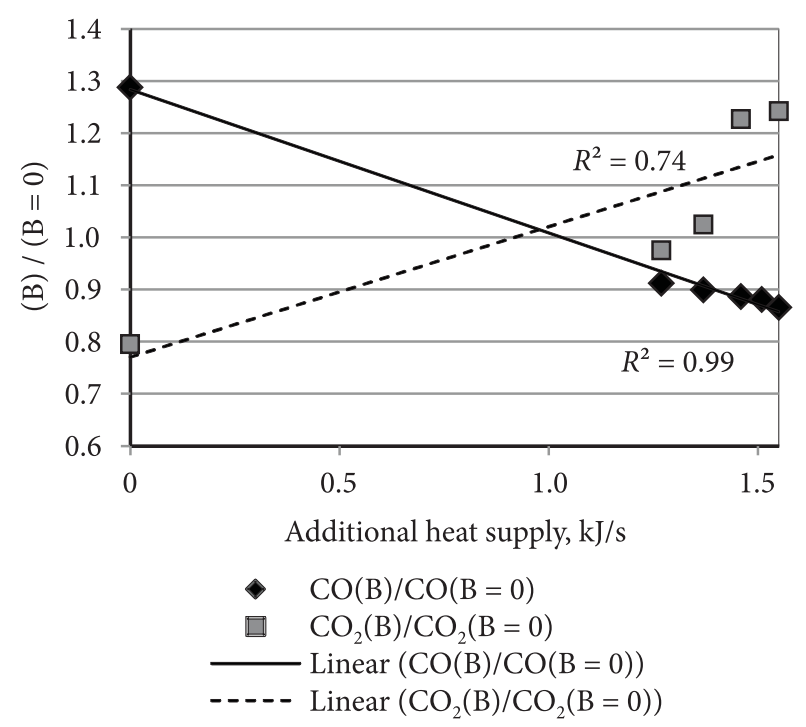

Fig. 12. Influence of propane-butane supply on $\mathrm{T}(\mathrm{B}) / \mathrm{T}(\mathrm{B}=0)$ and $\mathrm{NO}_{x}(\mathrm{~B}) / \mathrm{NO}_{x}(\mathrm{~B}=0)$ ratio

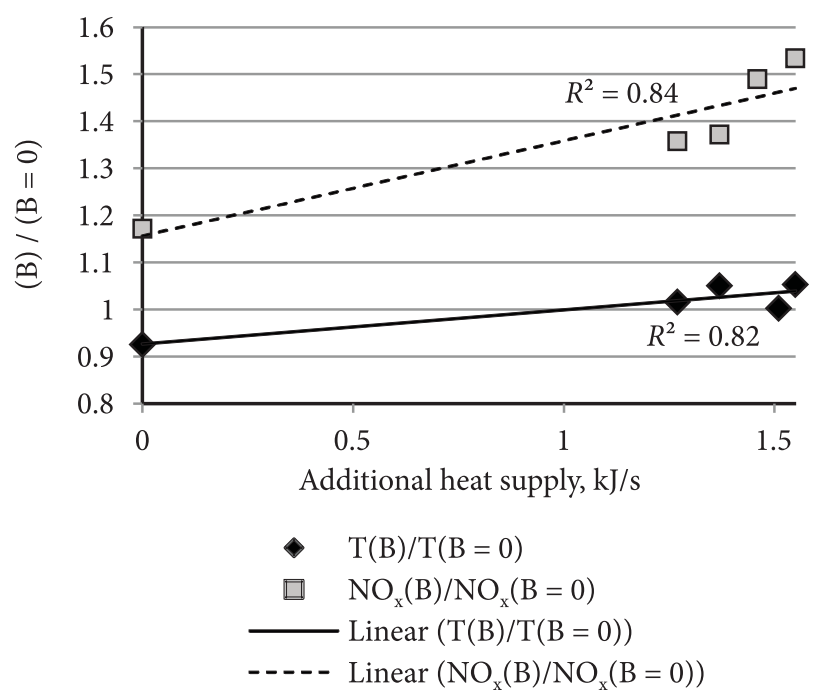

Fig. 13. Influence of propane-butane supply on $Q(B) / Q(B=0)$ and $\eta(B) / \eta(B=0)$ ratio thus increasing supply of propane-butane at the bottom of combustion zone. The figure shows that in all cases $\mathrm{NO}_{\mathrm{x}}(B) / \mathrm{NO}_{\mathrm{x}}(B=0)$ ratio is greater than 1 , which means that application of magnetic field intensifies formation of $\mathrm{NO}_{\mathrm{x}}$ with higher $\mathrm{NO}_{\mathrm{x}}$ emission release into the atmosphere. This should be evaluated as a negative result of the interaction between the field and the flame.

The effect of propane-butane supply on $\mathrm{NO}_{\mathrm{x}}(B) / \mathrm{NO}_{\mathrm{x}}$ $(B=0)$ is described with linear equation:

$$
\frac{N O_{x}(B)}{N O_{x}(B=0)}=0.20 q+1.16,
$$

where: $q$ - supply of propane-butane $(\mathrm{kW})$.

One of the most significant factors that influence formation of $\mathrm{NO}_{x}$ emissions is fluctuations of combustion zone temperature. Figure 12 shows that fluctuations of $\mathrm{T}(B) / \mathrm{T}(B=0)$ ratio depends on supply of propane-butane at the bottom of combustion zone. Temperature increases when supply of propane-butane is provided. Considering that oxygen transfer provided by the magnetic field simultaneously increases concentration of oxygen, combustion of the volatiles gets intensified. Influence of propane-butane supply on the temperature is described by the following linear equation:

$$
\frac{T(B)}{T(B=0)}=0.07 q+0.93,
$$

where: $q$ - supply of propane-butane $(\mathrm{kW})$.

The results of magnetic field and propane-butane supply effect on efficiency and heat production are shown in Figure 13.

In the result of interaction between the flame and magnetic field average efficiency of combustion process is higher than its efficiency in those cases, when magnetic field has not been applied and paramagnetic oxygen transfer towards gradient of the field has not been intensified.

The effect of propane-butane supply on $\eta(B) / \eta(B=$ 0 ) is described with following linear equation:

$$
\frac{\eta(B)}{\eta(B=0)}=0.07 q+0.90 \text {, }
$$

where: $q$ - supply of propane-butane $(\mathrm{kW})$.

Figure 13 shows influence of propane-butane supply on $Q(B) / Q(B=0)$ ratio, comparing produced heat energy $(\mathrm{kWh})$ in the experiments with and without application of magnetic field. Influence of propane-butane supply on the ratio $Q(B) / Q(B=0)$ is described with the following linear equation:

$$
\frac{Q(B)}{Q(B=0)}=0.08 q+0.98
$$

where: $q$ - supply of propane-butane $(\mathrm{kW})$.

In the result of interaction between the flame and magnetic field increase of produced heat energy is observed. It increases when supply of propane-butane to the device is increasing. 


\section{Conclusions}

Two possibilities were investigated in order to obtain complete wood pellets combustion for clean and effective heat energy production: wood pellets co-firing with propanebutane supply and magnetic field effect on combustion process.

The following conclusions were made in the result of co-firing of wood pellets with different moisture content ( $W=8 \%, 15 \%, 20 \%$ and $25 \%$ ) with supply of propanebutane:

Duration of thermal decomposition of wood pellets substantially depends on moisture content and supply of propane-butane. Moisture in the wood biomass delays formation and ignition of volatiles, as well as its combustion, in the process of which the highest temperature in the combustion zone is reached. Moist wood pellets ( $W=25 \%)$ combustion is unstable, temperature fluctuations are observed, the formation and ignition of volatiles is observed after $875^{\text {th }}$ second only, the average temperature is for $30 \%$ lower comparing with dry wood pellets $(W=8 \%)$ combustion. The propane-butane supply provides more stable moist wood combustion, faster formation and ignition of volatiles (479 ${ }^{\text {th }}$ second) and increase of the average temperature.

The analysis showed that formation of $\mathrm{CO}_{2}$ emissions in the process of wood pellets combustion is significantly influenced by the moisture content in the wood pellets: $\mathrm{CO}_{2}$ emission formation is reduced if moisture content increases, while CO emission volume increases. But during co-firing process formation, ignition, and combustion of volatiles is intensified, as well as formation of $\mathrm{CO}_{2}$ emissions in combustion products is increased, but concentration of $\mathrm{CO}$ emission is reduced.

The increase of temperature when wood pellets were combusted with propane-butane provided the increasing of $\mathrm{NO}_{\mathrm{x}}$ emissions comparing with wood pellets self-sustaining combustion.

Processing the experimental data on combustion efficiency showed that supply of propane-butane and changes of moisture content in the wood pellets influence efficiency of combustion process. It increases when supply of propane-butane in the combustion zone is increased and reduces when wood pellets moisture content is increased;

The following conclusions are drawn by analysing the influence of magnetic field during wood pellets sel-sustaining combustion and for co-firing with gaseous fossil fuel:

Applying of magnetic field provides the changes of velocity profiles - decreasing of axial and tangential velocity. It means that a longer residence time of volatiles in combustion zone is obtained.

Complete combustion of volatiles was provided with increased efficiency and heat energy production.

Applying of magnetic field and propane-butane supply during wood pellets combustion provides intensive combustion processes with an increase of temperature, in the result amount of $\mathrm{NO}_{\mathrm{x}}$ emissions also is increased.

The main conclusion of the recent research is that co-firing and magnetic field can be used to provide more effective heat energy production with more complete combustion of volatiles.

\section{Acknowledgments}

The authors are grateful to researchers Dr Phys. Maija Zake and Dr Sc.ing. Inesa Barmina from Institute of Physics, University of Latvia for their assistance and consultations in this research.

\section{References}

Al-Mansour, F.; Zuwala, J. 2010. An evaluation of biomass cofiring in Europe, Biomass and Bioenergy 34(5): 620-629. http://dx.doi.org/10.1016/j.biombioe.2010.01.004

Arena, U.; Zaccariello, L.; Mastellone, M. L. 2010. Gasification of natural and waste biomass in a pilot scale fluidized bed reactor, Combustion Science and Technology 182(4-6): 625-639. http://dx.doi.org/10.1080/00102200903467689

Arima, H.; Muto, H.; Jeyadevan, B.; Ymamaguchi, K.; Takahashi, J.; Fujita, T. 1999. The behavior of dissolved oxygen in gas oil using high gradient magnetic field, Magnetic and Electrical Separation 9(4): 199-211. http://dx.doi.org/10.1155/1999/26270

Balat, M. 2009. Gasification of biomass to produce gaseous products, energy sources, part A, Recovery, Utilization, and Environmental Effects 31(6): 516-526. http://dx.doi.org/10.1080/15567030802466847

Balat, M. 2008. Mechanisms of thermochemical biomass conversion processes. Part 2: reactions of gasification, energy sources, part A, Recovery, Utilization, and Environmental Effects 30(7): 636-648. http://dx.doi.org/10.1080/10407780600817600

Barmina, I.; Gedrovics, M.; Krishko, V.; Zake, M. 2009. Co-firing of the renewable with fossil fuel for the clean and effective heat energy production, Environmental and Climate Technologies 13: 21-29.

Bhattacharya, S. C.; Albina, D. O.; Khaing, A. M. 2002. Effect of selected parameters on performance and emission of biomass-fired cookstoves, Biomass and Bioenergy 23(5): 387-398. http://dx.doi.org/10.1016/S0961-9534(02)00062-4

Bignal, K. L.; Langridge, S.; Zhou, J. L. 2008. Release of polycyclic aromatic hydrocarbons, carbon monoxide and particulate matter from biomass combustion in a wood-fired boiler under varying boiler conditions, Atmospheric Environment 42(39): 8863-8871. http://dx.doi.org/10.1016/j.atmosenv.2008.09.013

Demirbas, A. 2004. Combustion characteristics of different biomass fuels, Progress in Energy and Combustion Science 30(2): 219-230. http://dx.doi.org/10.1016/j.pecs.2003.10.004

DongEnergy, Cofiring Gas and Wood Chips [online], [cited 30 April 2013]. Available from Internet: http://mail.inbox.lv/ horde/imp/view.php? mailbox $=$ INBOX\&index $=19636 \&$ arr ay_index $=22 \&$ id $=2 \&$ action $I D=$ view_attach 
European Commission, The EU climate and energy package [online], [cited 30 April 2013]. Available from Internet: http:// ec.europa.eu/clima/policies/package/index_en.htm

Gilard, V.; Gillon, P.; Blanchard, J.-N.; Sarh, B. 2008. Influence of a horizontal magnetic field on a co-flow methane/air diffusion flame, Combustion Science and Technology 180(10-11): 1920-1935. http://dx.doi.org/10.1080/00102200802261506

Van Loo, S; Koppejan, J. 2008. The handbook of biomass combustion \& co-firing. Chippenham, UK: CPI Antony Rowe. $442 \mathrm{p}$.

Nagaraju, K. 2005. Study of the effect magnetic field on the properties of combustion synthesized iron oxide nanoparticles: Thesis. Louisiana State University. 118 p.

Nussbaumer, T. 2003. Combustion and co-combustion of biomass: fundamentals, technologies, and primary measures for emission reduction, Energy \& Fuels 17(6): 1510-1521. http://dx.doi.org/10.1021/ef030031q

Obernberger, I.; Thek, G. 2004. Physical characterisation and chemical composition of densified biomass fuels with regard to their combustion behaviour, Biomass and Bioenergy 27(6): 653-669. http://dx.doi.org/10.1016/j.biombioe.2003.07.006

Shen, D. K.; Gu, S.; Luo, K. H.; Bridgwater, A. V.; Fang, M. X. 2009. Kinetic study on thermal decomposition of woods in oxidative environment, Fuel 88(6): 1024-1030. http://dx.doi.org/10.1016/j.fuel.2008.10.034

Stubenberger, G.; Scharler, R.; Zahirovics, S.; Obernberger, I. 2008. Experimental investigation of nitrogen species release from different solid biomass fuels as a basis for release models, Fuel 87(6): 793-806. http://dx.doi.org/10.1016/j.fuel.2007.05.034

Suzdalenko, V.; Zake, M.; Barmina, I.; Gedrovics, M. 2011. The effect of varying magnetic gradient on combution dynamic, Environmental and Climate Technologies 6: 100-105.

Swaminathan, S. 2005. Effects of magnetic field on micro flames: Thesis. Louisiana State University. 117 p.

Vassilev, S. V.; Baxter, D.; Andersen, L.; Vassileva, C. G. 2010. An overview of the chemical composition of biomass, Fuel 89(5): 913-933. http://dx.doi.org/10.1016/j.fuel.2009.10.022

Williams, A.; Jones, J. M.; Ma, L.; Pourkashanian, M. 2012. Pollutants from the combustion of solid biomass fuels, Progress in Energy and Combustion Science 38(2): 113-137. http://dx.doi.org/10.1016/j.pecs.2011.10.001

Yuntenwi, E.; MacCarty, N.; Still, D.; Ertel, J. 2008. Laboratory study of the effect of moisture content on heat transfer and combustion efficiency of three biomass cook stoves, Energy Sustainable Development XII(2): 66-77. http://dx.doi.org/10.1016/S0973-0826(08)60430-5

Zake, M.; Barmina, I.; Bucinieks, I.; Krishko, V. 2010. Magnetic field control of combustion dynamics of the swirling flame flow, Magnetohydrodynamics 46: 3-19.

Zake, M.; Barmina, I.; Krishko, V.; Gedrovics, M.; Desnickis, A. 2009. Experimental study of the combustion dynamics of renewable \& fossil fuel co-fire in swirling flame, Latvian Journal of Physics and Technical Sciences: 3-15.

Vera SUZDALENKO. Dr Sc.ing., Riga Technical University, Institute of Energy System and Environment. She is a coauthor of 12 scientific papers. The main research area is the investigation of renewable and fossil fuel co-firing and magnetic field effect on swirling combustion.

Martins GEDROVICS. Dr Sc.ing., Professor, Riga Technical University, Institute of Energy System and Environment. He is an author of about 80 publications. The main research area is combustion of biofuels. 